[seção Contextos]

\title{
NO ALTO DOS IMBU
}

\section{Hélio Márcio N. Lacerda ${ }^{1}$}

${ }^{1}$ Professor do Instituto Federal do Tocantins - (IFTO)

Contato principal: helio.lacerda@ifto.edu.br

\begin{abstract}
Resumo: Este texto apresenta algumas provocações sobre o ato de ler, fazer memória e sua relação com a escrita literária. Considero que esses três elementos fazem parte do meu processo criativo, uma vez que minha escrita se pauta, sobremaneira, por romances, cordéis e memórias (da infância) no sertão pernambucano. Assim, o conto a seguir pode ser lido como um exercício de ficcionalizar sobre a própria experiência, cruzando enredos literários e traços biográficos.
\end{abstract}

\begin{abstract}
This text presents some considerations about the exercise of reading, memory and its relation with the literary writing. I consider these three elements as part of my creative process, once my writing is based on novels' reading, cordel literature and memories (overall from childhood) in Pernambuco countryside. Then, this tale can be read as a fictional exercise about one's own experience, mixing literary plots with biographic features.
\end{abstract}

Era noite de verão, no Alto dos Imbu, quando pela madrugada José, de um pulo, levantou da cama. Suor frio e coração acelerado. Tivera outro sonho medonho! De espinhela arrepiada, benzeu-se algumas vezes até recobrar a fé de caboclo destemido. No escuro, tateou o fogo, acendeu o candeeiro, calçou a chinela de sola velha e couro fresco. Foi à cozinha, apanhou a caneca, raspou o pote quase vazio. Êta! Se tinha coisa que Ihe atacava era a sede em noite de visagem no sertão calorento e abafado.

Não soube exatamente o que sonhara. Entre vultos e sombras. Passados alguns instantes, conseguira divisar apenas uma forma quadrada, meio retangular. Com esforço, descobriria, no intervalo do pavor e no soluço do peito, que o estranho objeto a alguns metros adiante era um caixão deitado ali no outro lado da estrada. A curiosidade, com muito custo, vencera o medo, e o fez espreitar de mais perto. A perna bamba adiante, passo torto atrás, conferia um ar moribundo à sua carcaça baixa 
e esguia. O estranho que o visse diria se tratar de um esmoler que, certamente, bebera até secar os alambiques da região. Nada mais distante da verdade! Pois José, caboclo de pele queimada de sol e mãos calejadas de foice, era homem direito, que com cachaça não se melava, não sinhô! Não pra cair ou trocar o dia pela noite. Nada! Que se respeitasse o cabra e não o tirasse a pagode!

Cachacisse, mesmo, das braba, só uma vez numa Sexta de São João, quando o coração crepitou feito lenha na fogueira, e fez-lhe arrear os dois pneus da carroça por uma moça que, de batismo, atendia por Belunga. Mulata faceira, de passo firme e sorriso largo, tinha umas lapas de coxa bem torneada que só A Virgem! Cre'em Deus Pai! Trazia o corpo moreno em um vestido de algodão que, surrado de água barrenta e de sabão grosso era, certamente, a oitava maravilha! Cheiro de suor que o vento soprava... era puro Leite de Colônia que mexia no juízo dos cabras e os botava a perder.

A moça que trazia um par de seio a deslizar acima e abaixo, arfando o peito, parecia manteiga fresca triscando a taxa quente do cuscuz. O paraíso, se existia, morava ali, pensara José a primeira vez que seus olhos pretos, duas pitombas no cacho, foram sugados pelo instinto do cio e só pararam quando o olhar da moça tropeçou no seu e, enrubescido de vergonha, desviou o olhar. Belunga, de poucas letras, escuta ligeira e vasta curiosidade, brincava nas horas vagas de guardar palavras. Era uma guardadeira de palavras. Entre as varedas de buscar água e o caminho de casa, ia ruminando suas aquisições mais recentes, a recitar no ritmo lento dos passos.

Dia sim, dia também, era seu trabalho encher os potes da casa. Coisa dura de se fazer, mas, se a vida assim Ihe exigira o sacrifício diário, o que se havia de fazer contra os desígnios dos céus? Entre o calvário e o sacrifício, havia sua coleção de palavras guardadas em segredo, a sete chaves, que abria somente nesse instante de vaguidão dos passos no chão e lata d'água na cabeça. Sua coleção, em recente data, fora ampliada na visita do circo por aquelas paragens. Vira o circo de lona e palhaços trapezistas. Coisa bonita de se ver! Encher os olhos e molhar a alma!

Fora predestinado desde antes da fundação do mundo que, naquela noite, uma voz rouca chamaria a mulher-mamulengo, ao anunciar seu número e a dizê-la T-R-A- 
P-E-Z-I-S-T-A; essa palavra, uma flecha do tempo, a feriria no peito. Dito e feito. Fezse tatuagem em seu coração, uma noda de caju em roupa alva. Sentiu de sobressalto que, enquanto seus passos sobre o sertão caminhassem, enquanto o imbu desse chuva no mês de novembro, amaria aquela palavra e com ela faria amor.

Muitos anos depois, diante de seus colegas, havia de recordar daquela noite remota em que a ouvira pronunciada e pensaria em sua coleção de palavras, guardadas desde a infância, como uma chuva da qual nunca se seca inteiramente. Bela imagem! Palavras e pingos de chuva: molhar que não se seca nunca. Feito dor de morte que nunca passa.

Com baldes fazia trapezias. Do caminho da cacimba no rumo de casa, lata d'água na cabeça e um caldeirão em cada mão. Era trapezista. Assim imaginava a si mesma. Graças a Deus e a muito esforço, divisou essa palavra num cartaz de circo que, em outras épocas, passara por aquelas paragens, distrito pequeno de Mulungu. E nunca mais iria esquecer, nem por um só dia, daquelas letras garrafais na figura de uma trapezista. Mais ainda quando ouviu os sons, dançando feito bambolê na voz que a pronunciou. Aquela palavra, saída do anonimato e de pouco uso, faria José seguir o mesmo itinerário.

Pois numa tarde dessas de um dia quente, em sua casa, se viu com Belunga que ali fora levar um recado de seu pai. Entre olhares de desejo mútuo e reprimido, espiou-o desfolhar seu charme, feito nuvem prenha d'água em mês de março. De juízo doido e cacete também, lembraria mais tarde apenas do momento que a moça disse que estava com sede e pediu água. Também fora escrito, desde o mais pretérito dos tempos, que suas lembranças turvas seriam de corpo bonito, daquela carne macia apertada em suas mãos e dos beijos ensaboados de libido. Não lembraria, e se lembrasse não creria, que naquela cama de sabiá, estreita e apertada, coubera aquela mulher, bela - feito imbuzeiro no sertão quando, farto e maduro, espera ser colhido. Nos momentos que se seguiram, entre gozos e grunhidos monossilábicos, estranharia o pedido grunhido ao ouvido com aquela voz doce de fêmea no cio: "sussurra no meu ouvido T-R-A-P-E-Z-I-S-T-A"! T-R-A-P-E-Z-I-S-T-A!.

Ele, rapaz tímido e de poucas palavras, quedou-se, por instantes, deslocado. De repente, entre um gemido e o seguinte, pegou aquela palavra, empunhou-a com 
força e sussurrou em seu ouvido entre voz trêmula, medo e esguicho até que as carnes rijas se amoleceram no último suspiro. Nesse instante, soltou um gritinho - "Al! Gozei!". Pois bem, aquela mulé era coisa de outro mundo! Seria essa imagem que carregaria tempos e tempos depois. Sempre que a tristeza o roubava de si, acorria a essa cena que o devolvia de volta ao seu corpo, fazendo-o fincar os pés no chão e na realidade.

Naquela madrugada, José recebera um mensageiro e um caixão que fora entregue em sua porta por remetente desconhecido dos vivos! Benzeu-se outra vez! Rezou o rosário ao contrário para fechar o corpo como ensinara sua avó, a benzedeira Maria Israelita, que há muito também se benzera dessa vida e partira para próxima a ver melhor morada que essa do sertão, de dores em enchente e alegrias em gota, pingando da telha. De corpo fechado, teve coragem de bizoiar a mensagem trazida do além em madeira fresca, ainda soltando nódoa.

Divisou o caixão; com passos incertos contou dez até chegar perto. Espichou de canto de olho. Para seu espanto, vira ali um rosto moreno do sol, barba rala e feição familiar. Mais tarde, contaria para quem quisesse ouvir e mesmo aos que se recusassem que, ao ver o defunto, vira também a si, empacotado. Naquela noite alta de maio, dessas que o sol faz arder a madrugada como se fosse meio-dia, José vira seu irmão Neném, defuntado. Uma dor de parir o coração lanhou-Ihe no peito. Era seu irmão! Mas não podia ser! Exclamou para si, para, em seguida, arrebentar a garganta de um nó cego, desses que não desatam em água, nem com o cão!

Neném, aquele menino que, além de traquino, fora seu maior cúmplice nas encrencas de infância, agora estava ali na sua frente, inerte, no formato que os vivos assumem quando mortos: rosto pálido, lábios secos, mãos ao peito em cruz, olhos cerrados e cenho sisudo. Não obstante a cena de desterro que lhe rachou a cabeça, José com algum esforço fechou os olhos e viu naquele rosto um riso que acolhia [como sempre acolhera] sua dor e onde ele quis, por um instante, fazer morada. Vira brevemente essa expressão de moleque que vacila nos intervalos de dor e alegria de passarinhar. Sim, era isso. Sim, era essa a cena.

Ali estava não apenas um corpo de alguém cuja causa mortis se desconhecia, mas, antes, alguém cujo olhar de cumplicidade lhe alcançava sempre e lhe fora, vezes 
sem conta, fortaleza e alegria. José lera sobre a infância uma bela frase que agora com força se recordava: "a infância é um país para onde sempre se pode ir... uma chuva da qual que nunca se seca inteiramente". Essa frase reverberaria em sua cabeça o resto das secas que tinha pela frente. E não eram poucas! Ao abrir os olhos, a cena do caixão o sugou para si. Dos passantes e curiosos, esperou a mão de alguma ajuda, que não veio. Com custo, arrastou o caixão para sua porta. Já cheirava mal. Os vermes, cemitério vivo à espera dos mortos, sempre pontuais, sem margens para atraso, já faziam o trabalho que o Criador [ou o Demônio] Ihes incumbira.

Era já dia quando o sol alto caminhava no céu. José, olhos inchados de remela e água, esfregava-os como se tentasse, nesse ato, espantar os maus agoiros. Aquele dia, embora igual a tudo, seria diferente de todos. Pegou do bule e passou um café. Amargo e sem açúcar. Era assim que tomava. Não por gosto, menos ainda por escolha. Mas porque nunca conseguira calcular a medida certa de pó e grãos de açúcar. "Tomei do café que eu mesmo preparei", pensou. $\mathrm{O}$ dia vagava-Ihe $\mathrm{O}$ pensamento. De tão solto, não divisava nada na paisagem, além de seu mal-estar. Almoçaria na tarde o sobejo requentado de ontem, ritual que se repetira na janta. Metáfora de sua vida. Entre idas e vindas, ausências e faltas, tinha sido assim esses anos. Se não foram todos, ao menos aqueles que trazia na memória o foram.

Era tardinha quando ouviu de casa estrondos que machucaram seu ouvido. Seguindo o instinto do susto, surgiu um espasmo logo contido pela imaginação de que eram rojões fora de época. Permaneceu imóvel, apenas os olhos se moviam. Entre uma frase e outra, atentou para o relógio que já passava de cinco e o sol já ia alto. Calçou a chinela, abriu a porta para uma cena de filme: 5 carros de polícia para cada legião de curiosos que ali estavam - feito plateia a esperar o início do espetáculo. À frente, a alguns metros, uma bicicleta vinho, um rapaz caído sobre os ombros, cabeça curvada ao peito, pernas rijas, encurvadas, escondia uma pequena poça de sangue. A José, o filho dos Imbu, não de Itabira, ocorreu que:

"os tiros na madrugada liquidaram seu leiteiro. Se era noivo, se era virgem, se era alegre, se era bom, não sei, é tarde para saber. A noite [...] prossegue, a manhã custa a chegar, mas o leiteiro estatelado, ao relento, perdeu a pressa que tinha. $\mathrm{Da}$ garrafa estilhaçada, no ladrilho já sereno escorre uma coisa espessa que é leite, 
sangue... não sei.

Por entre objetos confusos, mal redimidos da noite, duas cores se procuram, suavemente se tocam"...

Era um corpo circundado de morte e desamparo, que vertera o vento em dor e aquela tarde em tristeza. 